\title{
矩形流路内温度助走区間における正三角柱乱れ促進体挿入による伝熱促進
}

\section{鄭 仁基}

\author{
嶺南大学校工科大学 機械工学科 ${ }^{\dagger \dagger}$
}

\section{中山＼cjkstart顕・荒木信幸}

\section{静岡大学工学部 エネルギー機械工学科 ${ }^{\dagger \dagger}$}

\begin{abstract}
矩形流路内で流体力学的に十分発達した等温壁温度助走区間において正三角柱乱れ促進 体を挿入した場合の対流熱伝達の促進効果をナフタリン昇華法による物質移動係数の測定 によって明らかにした. 油膜法による流れの可視化および壁面静圧分布の測定も合わせて 行い，ポンプ動カ一定の条件の下で，伝熱面と促進体間の間隙，三角柱の迎角およびレイ ノルズ数が伝熱性能に及ぼす影響を検討した。本実験の結果より，三角柱促進体の迎角 $\theta$ $=60^{\circ}, \quad$ 間げき比 $\boldsymbol{c} / \boldsymbol{a}=0.5$ の場合が最も高い性能比を示し, 温度助走区間においても低 レイノルズ数領域ではかなり高い促進効果を得ることが分かった。
\end{abstract}

\section{緒言}

流路内に乱れ促進体を挿入する方法は有効な伝熱促進 手段の一つとして従来から注目されており, 数多くの研 究が行われてきた。 その中で, 二次元柱状物体を伝熱面 から浮かせて設置する方法 ${ }^{4,8 \sim 11,14,15,18)}$ では，物体と 伝熱面間の間隙で流れの加速が生ずるとともに，物体の 上下面から剝離されたせん断流が再付着点近傍で強い乱 れ域を形成するため，促進体直下からかなり下流の広範 囲な領域において高い熱伝達率の維持が可能となる。さ らに促進体加ら放出うずによる流れの非定常性が加わ ることで高い伝熱促進効果が期待できるとの報告がある。 一方，宮下ら ${ }^{9)}$ は作動流体として高プラントル数流体を 用いた実験によって平均熱伝達摔が間隙がない場合より 減少することを報告しており，また鈴木ら ${ }^{15)}$ は角柱を挿 入した平行平板流路内の非定常層流に関する数值実験加 らその間隙が小さいほどむしろ平滑流路より伝熱の劣化 が生じることを報告している。これらの報告は，この種 の伝熱系において, 促進体の挿入位置, また流体力学的 および熱的境界条件などが伝熱特性に極めて大きく影響 を及ぼすことを示唆している。したがって，より多様な 研究の必要性が認められる。

なお実際の応用においては，乱れ促進体の挿入に伴う

\footnotetext{
$\dagger 1994$ 年 1 月 28 日受理

†† $\overline{7} 712-749$ 韓国 慶山市大洞 214-1

†† $\bar{\dagger} 432$ 浜松市城北 3-5-1
}

圧力損失の増大, 流路内の熱的未発達領域に関する補正 が問題となる，従来の研究においては，伝熱性能を評価 したものは少なく，特に流れが発達した温度助走区間に おける研究は見当たらない，そこで著者らは，矩形断面 流路内で流体力学的に十分発達した状況下の等温壁温度 助走区間に注目し，柱状乱れ促進体を挿入した場合の伝 熱促進効果を詳細に調べた。以前，著者 $ら^{2 ; 3)}$ は，促進 体として正方形柱を用いて，非定常層流に関する数值実 験および物質移動実験を行い，促進体下流ですきま流の 㔀離・再付着を確認した。また伝熱（物質移動）性能評 価より, 温度 (濃度) 助走区間においても熱的に発達し た場合で得られる程伝熱促進効果は期待できないものの, 最適間隙比および迎角を設定することで，比較的高効率 の乱れ促進体となりうることなどがわかった。

本報では，促進体の形状として正三角形断面を有する 三角柱を取り上げ，三角柱の迎角および伝熱面との間隙, レイノルズ数が伝熱および摩擦特性に及ぼす影響を実験 的に検討した。ナフタリン昇華法による局所物質移動係 数および壁面静圧分布を測定し，ポンプ動力一定の条件 下で性能評価を試みた。なお油膜法を用いた流れの可視 化実験により促進体の周りおよび物質移動面における流 動パターンの詳細を明らかにした。

\section{1. 実験装置および方法}

\section{$1 \cdot 1$ 実験装置}

本実験に用いた風胴は高さ $25 \mathrm{~mm}$, 幅 $150 \mathrm{~mm}$ の矩 形断面を有する全長 $3000 \mathrm{~mm}$ の直線流路であり，流路 


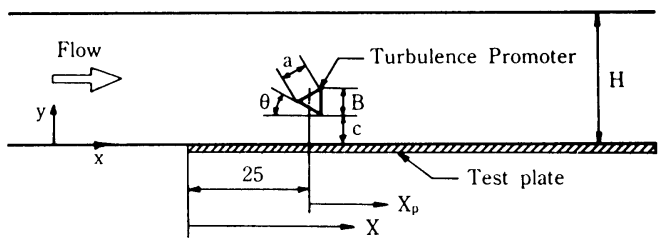

Fig. 1 Schematic view of test section

系は吸込開放型である。作動流体（空気）は上流流路, 測定部，下流流路および流量調節部を経て屋外へ排出さ れる. Fig. 1 に測定部の概略図を示す，測定部は流路入 口から $1775 \mathrm{~mm}\left(40 D_{h}\right)$ の下流の長さ $200 \mathrm{~mm}$ とし, 矩 形流路の下壁部を構成しており, 実験目的に応じて, 物 質移動係数測定用のナフタリン試片, 壁面静圧測定用あ るいは流れ可視化実験用のアクリル板が取り付けられる ようになっている。乱れ促進体は測定部の前縁から 25 $\mathrm{mm}$ の下流にスパン方向に挿入する.（ $X_{p}$ の原点は促進 体断面の中心にとる.）ナフタリン試片は鋳造法で製作 し，その表面温度を測定するため 2 本の銅ーコンスタン タン熱電対を埋め込んである. また, 静圧測定用のアク リル板には流れ方向に $3 \sim 5 \mathrm{~mm}$ の間隙で静圧孔（0.5 $\mathrm{mm} \phi)$ を開け，測定部前縁より上流 $30 \mathrm{~mm}$ の位置に は基準静圧孔が設けられている.

\section{$1 \cdot 2$ 実験方法}

矩形流路内の流れが十分発達した領域で温度（濃度） 場が発達しつつある条件を設定して実験を行った．定温 度型熱線風速計を用いた速度場の測定の結果, 主流は乱 れ強さ $0.3 \%$ 以下の発達した乱流状態で測定部に流入し ており，また流れの二次元性む確認した.

物質移動係数の測定にはナフタリン昇華法を用いた. ナフタリンの局所昇華量は, 分解能 $0.001 \mathrm{~mm}$ の触針式 深さゲージセンサと自動移送式 $\mathrm{X}-\mathrm{Y}$ テーブルで構成さ れた測定装置によって，スパン方向に $20 \mathrm{~mm}$ ，流れ方 向に $2 \mathrm{~mm}$ の間隙で測定した。 センサからの出力は $\mathrm{A} /$ $\mathrm{D}$ 变換器を経て直接マイクロコンピュータに収録した。

Fig. 2 に本実験で使用した乱れ促進体の形状と寸法を 示す. 促進体は辺長 $5 \mathrm{~mm}$ の正三角柱として，流れ方 向に対する迎角を $\theta=0^{\circ}, 30^{\circ}, 60^{\circ}$ 打よび $90^{\circ}$ 之変化さ せ設置した．この際，流路内の三角柱のブロッケージ比 は $B / H=0.17 \sim 0.20$ の範囲となる. また比較のために 三角柱の辺長と同じ直径を有する円柱についても合わせ て実験を行った。なお，促進体と伝熱面との間隙は $c=$ 1〜8 mm まで段階的に変化させ, 三角柱の辺長（ま たは円柱の直径）との比（以下間隙比と呼ぶ）が $c / a=$ 0.2, 0.5, 0.8, 1.3 および 1.6 となるよう設定した. 実験は, 矩形流路の水力直径 $\left(D_{h}=42.9 \mathrm{~mm}\right)$ 之断面平均流速

\begin{tabular}{|c|c|c|c|c|}
\hline \multicolumn{3}{|c|}{ Turbulence } & \multirow{2}{*}{$\begin{array}{c}\text { Attack Angle } \\
\theta[\text { deg }]\end{array}$} & \multirow{2}{*}{$\begin{array}{c}\text { Blockage Ratio } \\
\text { B/H [-] }\end{array}$} \\
\hline Type & Configura & ation & & \\
\hline \multirow{4}{*}{$\begin{array}{c}\text { Triangular } \\
\text { Prism }\end{array}$} & $\underset{\rightarrow}{\operatorname{lilow}} \Delta \mathbb{a}^{\mathrm{a}}$ & \multirow{4}{*}{$a=5 \mathrm{~mm}$} & 0 & 0.17 \\
\hline & $\rightarrow_{\theta}$ & & 30 & 0.20 \\
\hline & $\rightarrow \nabla_{B}$ & & 60 & 0.17 \\
\hline & $\rightarrow D$ & & 90 & 0.20 \\
\hline $\begin{array}{l}\text { Circular } \\
\text { Cylinder }\end{array}$ & $\rightarrow \mathrm{O}_{\mathrm{I}} \mathrm{d}$ & $\mathrm{d}=5 \mathrm{~mm}$ & - & 0.20 \\
\hline
\end{tabular}

Fig. 2 Shape and dimensions of turbulence promoters

$\left(U_{m}\right)$ に基づくレイノルズ数を $\operatorname{Re}\left(D_{h} U_{m} / \nu\right)=4960,8270$, 13780 および 22050 に設定し, 比較的に低乱流域で行っ た.

また, 物質移動面と促進体周りの流れパターンを観察 するために測定部の底面および流路中央に流れと平行に 垂直面を設け，定性的現象の把握を目的として油膜法を 用いて流れの可視化を試みた。 可視化実験は, 辺長 10 $\mathrm{mm}$ の三角柱を用いて主流速度 $8 \mathrm{~m} / \mathrm{s}(R e=22050)$ で 行った.

\section{$1 \cdot 3$ 測定データの処理}

以下に本測定デー夕の処理方法の概略を述べる，局所 物質移動係数 $K(X)$ は時間 $\Delta t$ の間に生ずる局所昇華深 さの差 $\Delta \tau(X)$ 加次式によって算出する.

$$
K(X)=\rho_{s} \Delta \tau(X) / \Delta t\left\{C_{w}-C_{b}(X)\right\}
$$

ここで， $C_{w}$ は昇華表面におけるナフタリン飽和蒸気 の濃度で, Sogin ${ }^{12)}$ に基づきナフタリン蒸気の圧力-温 度関係式之理想気体の状態式から求める。 また, 主流中 のナフタリン濃度 $C_{b}(X)$ は次式により計算する ${ }^{13)}$.

$$
C_{b}(X)=\left(\rho_{s} W / \Delta t Q\right) \int_{0}^{X} \Delta \tau(x) d x
$$

Eq. （1）で求めた $K$ は局所シャーウッド数 $S h(=$ $\left.K D_{h} \mathrm{Sc} / \nu\right)$ で整理し，この際空気中へのナフタリンの 拡散に対するシュミット数 $S c$ の算出においては次式 を使用した。

$$
S c=8.0743 T^{-0.2165}
$$

次に, 壁面静圧係数は測定部での静圧と基準静圧との 差圧から $C_{p}=2\left(p-p_{0}\right) / \rho U_{m}{ }^{2}$ の式により算出した。 ま た流路摩擦損失係数 $f$ は, 圧力降下 $\Delta p$ により次式で求 めた。

$$
f=\Delta p /\left\{\left(L / D_{h}{ }^{*}\right)\left(\rho U_{m}{ }^{2} / 2\right)\right\}
$$

ここで， $D_{h}{ }^{*}$ は Jones ${ }^{6)}$ が提案した修正水力直径であ り, 本実験装置の場合は $D_{h}{ }^{*}=0.81 D_{h}$ に対応する.

なお，本実験に㧍ける測定值の不確かさをデー夕収集 に伴う誤差のみとし，Kline $ら^{7)}$ の方法に基づき求めた 結果, レイノルズ数 $R e=8270$ の場合, 包括度 $95 \%$ の 


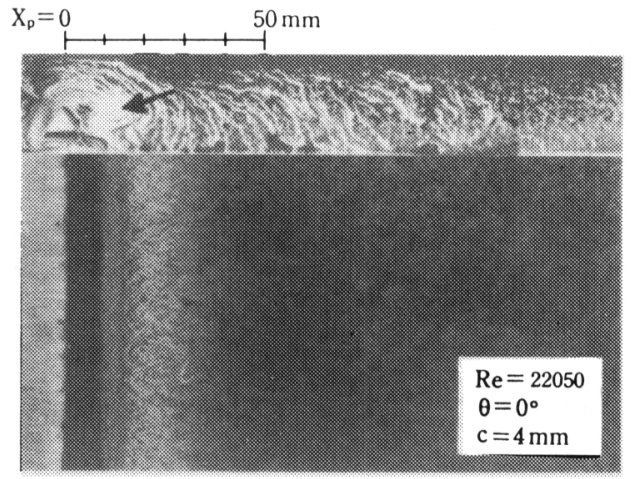

Fig. 3 A typical photograph obtained from flow visualization by oil-film method

不確かさは次のようになった。

$$
\begin{aligned}
& U_{R e}= \pm 3.2 \%, \quad U_{s h}= \pm 3.5 \%, \quad U_{s h m}= \pm 3.8 \%, \\
& U_{f}= \pm 9.5 \%
\end{aligned}
$$

\section{2. 実験結果および考察}

\section{$2 \cdot 1$ 局所物質移動係数およひ壁面静圧係数}

1) 流れの可視化 Fig. 3 に迎角 $\theta=0^{\circ}$ の三角 柱の間隙 $c=4 \mathrm{~mm}$ の場合について, 三角柱周りおよび その下部物質移動面に抢ける流机の可視化写真を示す. 三角柱の後方で流れが巻き込まれ再循環渦（図中矢印） が形成されている。 また下壁面においては, 三角柱の直 下で間隙流の加速执よび三角柱下面からのせん断流が再 付着し強い乱れを形成するに至る, 藤田ら ${ }^{4)}$ が観察した と同様のパターンがうかがわれる.このパターンは, 後 述する局所物質移動係数の分布に深く関連している。 ま た, Fig. $4(\mathrm{a})$ には $c=2.5 \mathrm{~mm}$ で三角柱の迎角を变化さ せた場合之，参考のため円柱と壁面之の間隙を变化させ た場合の促進体周りの流れパターンの変化を示す．三角 柱の場合, 同じ間隙においても迎角が異なると, 後方の うずの位置と流れのパターンに変化が生ずる．また円柱 の場合, $c$ の増加に伴って間隙流の速度が一旦増加し, この流れの巻き込みによるうずの位置が下流に移動する が, $c=4 \mathrm{~mm}$ 以上になるとうずが再び物体後面に接近 しカルマンうず型の流れへと変化する様子が分かる（図 中矢印参照)。これは，谷口ら ${ }^{17)}$ の正方形柱による実験 結果とあょく一致しており，促進体による伝熱促進およ び圧力損失と深く関連している.

一方, Fig. 4 (b)には $c=1 \mathrm{~mm}$ の場合について, 促進 体の姿勢および形状の変化に伴う下部壁面での流饥 ターンの変化を示している。、いずれの場合にも促進体の 直下で間隙流による強い流れパターンが現れている. 特 に $\theta \neq 0^{\circ}$ の三角柱抢よび円柱の場合, 促進体前面で衝

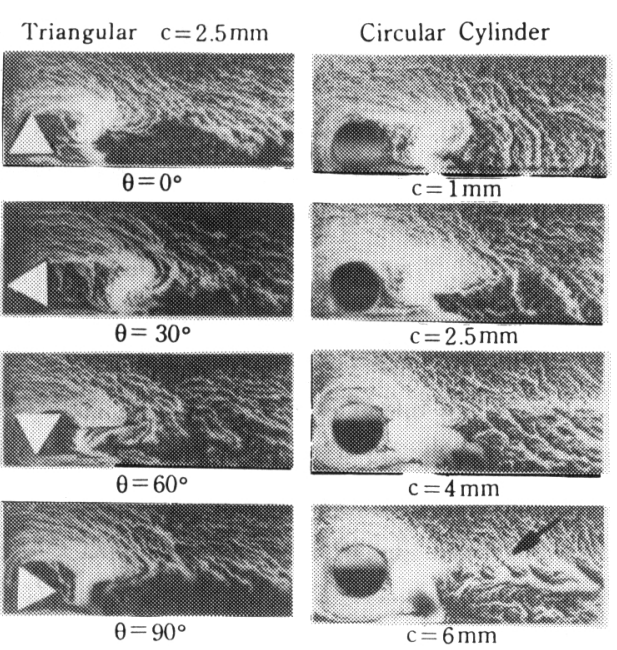

(a) Flow pattern around a turbulence promoter
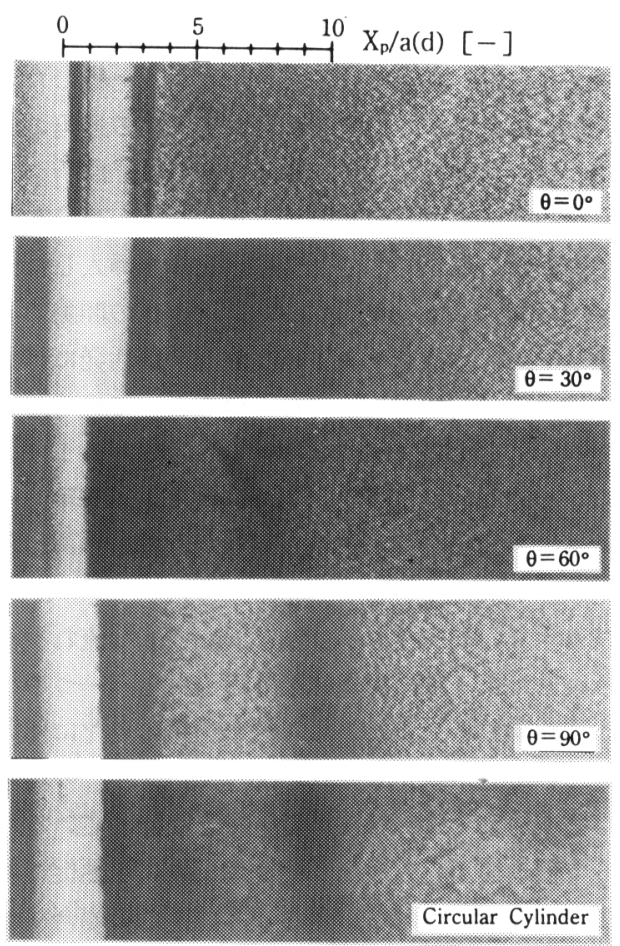

(b) Flow pattern reflected on mass transfer surface; $c=1 \mathrm{~mm}$

Fig. 4 Photographs from flow visualization by oil-film method; $R e=22050$

乫した流れの一部が下降して間隙を通過するのでこの軌 跡がもっ之顕著に現れている．また，間隙の増加と共に この白い帯の幅は狭まるが，新たに（Fig. 3 が示唆する ような）促進体下面からはく離したせん断流の再付着地 
点に対応する白い領域が現れる。なお，三角柱の $\theta=$ $0^{\circ}$ の場合には，促進体の直下およびやや下流において 強い壁面せん断流による白い帯が二つ現れている。これ はそれぞれ間隙流と三角柱上端からのはく離せん断層が 壁面に接することに起因する。，下流側の帯は， $c \geqq 2$ $\mathrm{mm}$ 以上になると消えてしまう。しかしながら，他の 間隙がある場合には促進体の上面からはく離したせん断 流の再付着に対応する流れ軌跡は明確には現れない。

2）局所物質移動係数の分布 本実験で測定部は, 流れが十分発達した温度（濃度）助走区間にある。乱れ 促進体を挿入しない（平滑）流路における局所シャ一 ウッド数の分布は, 濃度境界層が薄い先端付近で勾配が 急であるが下流に行くほどほとんど平坦な分布となる. これを管内乱流熱伝達に関する Gnielinski ${ }^{5)}$ の式を助走 区間に拡張した次式

$$
S h_{s}=0.0214\left(R e_{s}^{0.8}-100\right) S c^{0.4}\left\{1+\left(D_{h} / X\right)^{2 / 3}\right\}
$$

と比較した結果, 測定值は Eq. (5) とよく一致した.

Fig. 5 (a)および(b)には，それぞれ三角柱の迎角および 間隙比が物質移動促進に及ぼす影響を示す．局所シャー ウッド数の平滑流路の值に対する比 $S h / S h_{s}$ の分布形状 は，伝熱面から浮かせて二次元柱状物体を挿入した場合 の典型的なパターンを示している．壁面との間隙で流れ の加速が生ずる物体直下および乱流混合が活発に行われ る間隙流の再付着位置近傍で極大值をとっている。す すな わち促進体前方の減速域でいったん $S h / S h_{s}$ は 1 以下と なるが，間隙流の加速効果により急激に上昇し第一極大 值をとる，その後間隙を出た流れははく離し，再付着す る際に第二極大值をとる. 同図(a)に扔いて， $c / a=0.2$ および $\theta=0^{\circ}$ の三角柱の場合, Fig. 4 (b)の流れパ夕ー ンで示唆したように, 促進体後方近くにもう一つの小さ な極大值が現れる。 また，三角柱の迎角の変化に伴い極 大值をとる位置が变化し， $\theta=60^{\circ}$ および $90^{\circ}$ の場合に はかなり下流まで $S h / S h_{s}$ が高い值を維持している。し たがって促進体からの放出うずが効果的に伝熱促進に寄 与していると考えられる。 さらに，いずれの場合にも三 角柱の方が円柱に比べて伝熱促進効果が大きい，また同 図(b)に示すように，促進体の下部で現れる第一極大值は, 間隙比の増加に伴い次第に減少し, その発生位置は促進 体直下にほぼ固定されている。しかし第二極大值は，間 隙比の増加之ともに増加後再び減少し，その位置も上流 に移動したのち再び下流に移動する。ここでは， $\theta=$ $60^{\circ}$ の三角柱の場合のみを示したが，本研究で用いた他 の促進体の場合においても同じ傾向を示している。これ はFig. 4 (a)で見るように，物体後方での流れの巻き込 みによるうずの位置の移動や下流に形成される再循環う
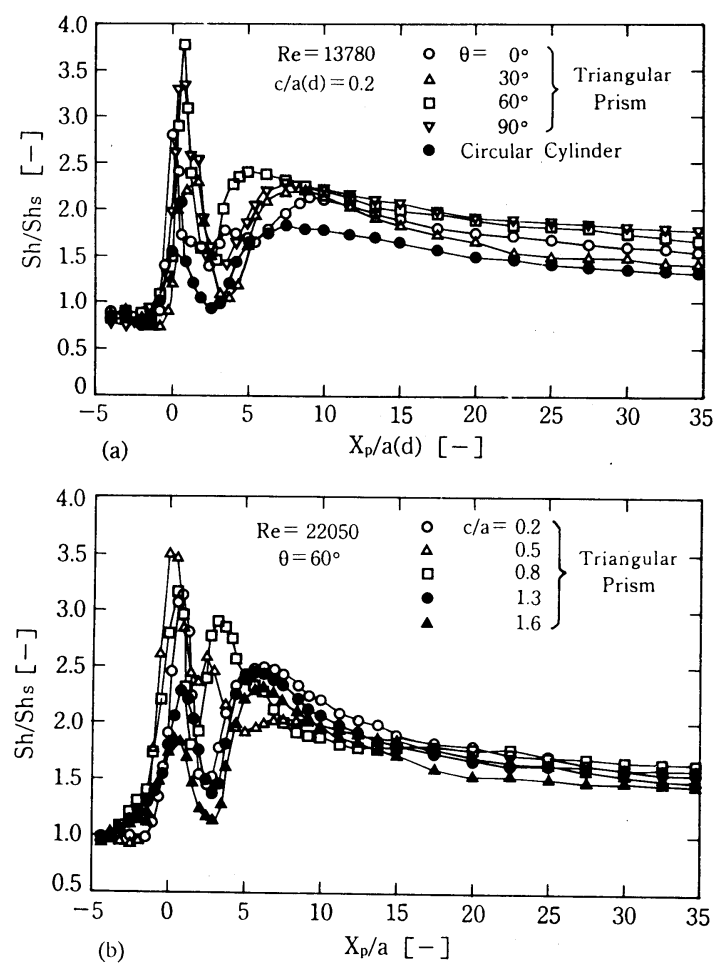

Fig. 5 Distributions of local Sherwood numbers; Effects of (a) the angle of attack, and (b) the clearance ratio on $S h / S h_{s}$

ずの大きさに対応していると考えられる。

Fig. 6 (a)および(b)にはそれぞれ $S h / S h_{s}$ の第一および 第二極大值の変化をレイノルズ数の関数として示す。こ れらの值は, 間隙比の増加と共に増加して $c / a=0.8$ 付 近でピークに達しその後減少する傾向を示すことから， ここでは, $c / a=0.8$ について三角柱の迎角变化をパラ メー夕として示してある. 第一極大值および第二極大値 共にレイノルズ数が増加するにつれて単調に減少してい るが，その傾向は第一極大值の方が顕著である．また多 少テータのばらつきがあるあのの，いずれも迎角 $\theta=$ $60^{\circ}$ および $90^{\circ}$ の方が $0^{\circ}$ および $30^{\circ}$ の場合に比べ高い 值をとり，第一極大值の場合その差が極めて大きい，こ れは迎角が大きくなるほよ゙角柱前面に衝突した流れが下 降して壁面に強く衝突するためと考えられる.

3）壁面静圧係数の分布 Fig. 7 には $R e=13780$ の場合について, $\theta=30^{\circ}$ の三角柱を挿入したときの下 部壁面における静圧係数 $C_{p}$ の分布を間隙比をパラメー 夕として示す. 比較のために $c / d=0.2$ の円柱に対して 屯示している. 間隙が狭い時には促進体の前で流れがせ き止められ圧力が上昇したのち急激に降下するため促進 体直下で負圧の谷が生じる，再び圧力は促進体直後から 


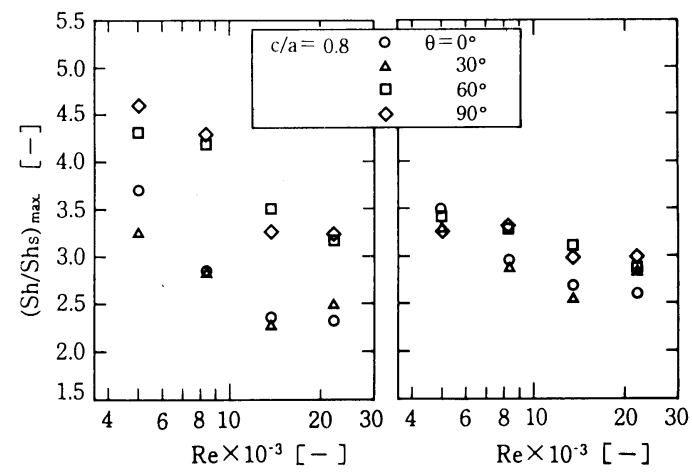

(a) 1 st maximum valuc (b) 2nd maximum value

Fig. 6 Maximum values of local Sherwood number

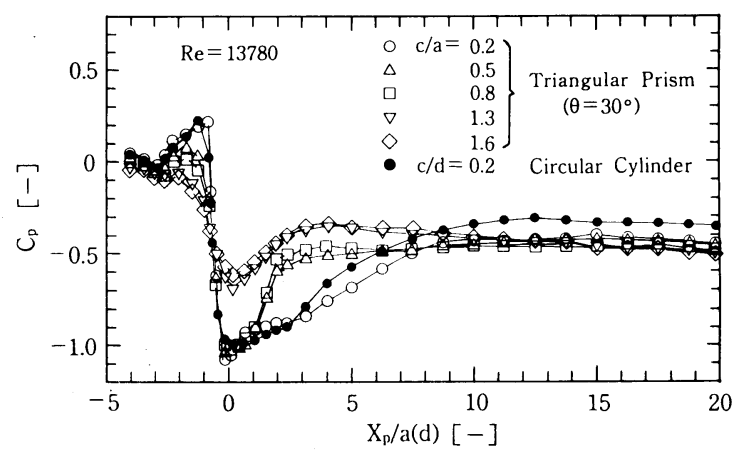

Fig. 7 Distribution of pressure loss coefficients

回復するが, $c / a=0.2$ の場合には三角柱, 円柱共に圧 力回復が緩やかになる。この状況下ではまだはく離停滞 泡から周期性の放出うずへと変化する臨界間隙比 ${ }^{17)}$ 以下 であり，間隙を通る流れは壁噴流に近い状態となってい る. 間隙比が増加するほど正圧と負圧の差は小さくなる.

\section{$2 \cdot 2$ 平均物質移動係数および摩擦損失係数}

乱れ促進体の形状，姿勢および間隙比が及ぼす物質移 動および圧力損失特性の変化を比較するために, $X=$ $35 a$ にわたる測定デー夕を積分し, 平均シャーウッド 数 $S h_{m}$ および流路摩擦損失係数 $f$ を求めた.

Fig. 8 には, 円柱について $S h_{m}$ と $f$ をそれぞれ平滑 流路の結果と共に示し, 左図には参考のために熱的に十 分発達した場合に対する Dittus-Boelter の式を実線で 示している. また図の中の Eq.（6)と Eq.（7）はそれ ぞれ平滑流路について, Eq.（5）を測定区間にわたり積 分した平均シャーウッド数の式

$$
S h_{m s}=0.0381\left(R e_{s}^{0.8}-100\right) S c^{0.4}
$$

抒よび管内乱流摩擦損失係数に関する KàrmánNikuradse $の$ 式 ${ }^{16)}$

$$
f_{s}=\left(1.82 \log R e^{*}-1.64\right)^{-2}
$$

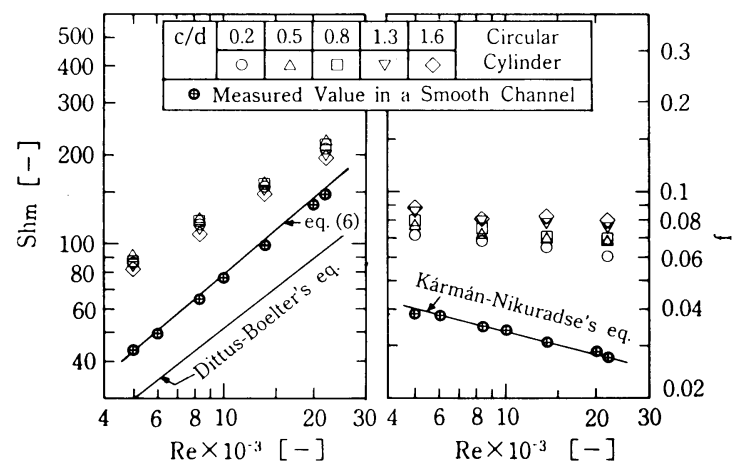

Fig. $8 S h_{m}$ and $f$ for the circular cylinder, and comparison with them for the smooth channel

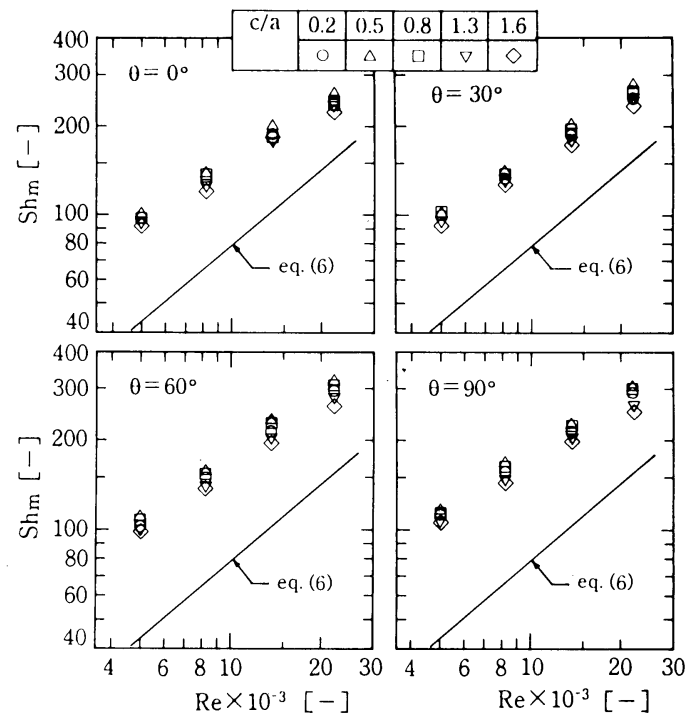

Fig. 9 Average Sherwood number for triangular prism

を示す．測定值は上式と良好な一致を示しており，本実 験系の妥当性が認められる. 同図の $S h_{m}$ と Fig. 9 の三 角柱の $S h_{m}$ を共に比較すると, 促進体を挿入した場合, $S h_{m}$ のレイノルズ数への依存性が平滑流路のそれに比 べて小さいことが分かる。すすおち $S h_{m} \propto R e^{m}$ として 相関させると，レイノルズ数のべき指数 $m$ は，円柱の 場合 $m=0.58 \sim 0.60$, 角柱の $\theta=0^{\circ}, 30^{\circ}$ および $90^{\circ}$ の 場合 $m=0.60 \sim 0.66$, また $\theta=60^{\circ}$ では $m=0.70 \sim$ 0.72 の範囲内の值が得られる。これは宮下ら ${ }^{9)}$ が得た値 に比して多少大きいが, その傾向はよく一致している. 間隙比の影響は，本実験の範囲ではあまり大きく現れな いが，いずれの場合にも $c / a(d)=0.5$ の場合が最も $S h_{m}$ が大きい，迎角については， $\theta=60^{\circ}$ および $90^{\circ}$ の 場合が顕著に高い $S h_{m}$ を示す。なお，三角柱では同一 条件下の円柱に比べいずれの場合も高い物質移動係数が 


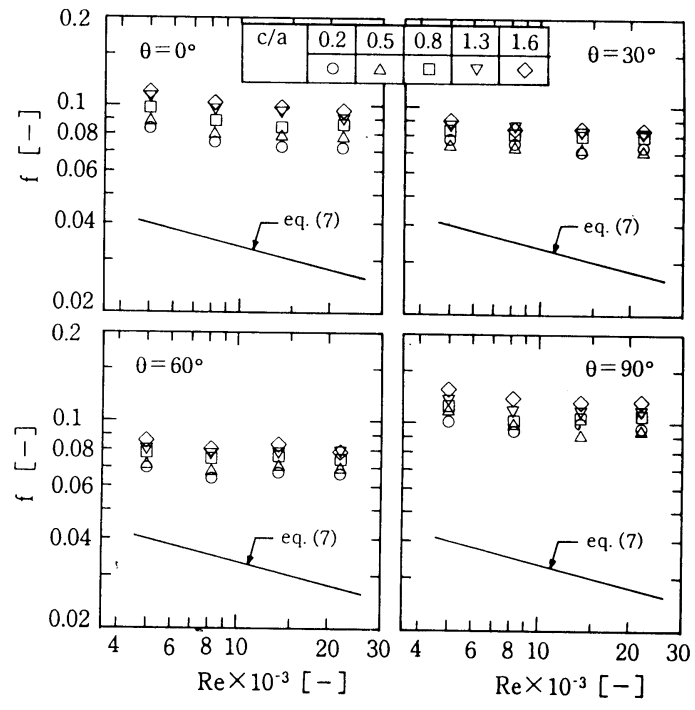

Fig. 10 Friction factor for triangular prism

得られる.

一方，摩擦損失係数について，Fig. 8 の右図と Fig.10 を比較する際， $f$ のレイノルズ数に対する依存性が小さ く一定值をとることが分かる，そのレベルは，間隙比の 増加とともに増加する．これは前述の上うに間隙の増加 につれ促進体の背圧が減少し物体の抗力が増加するため と考えられる.いずれの場合む三角柱の方が円柱に比べ 摩擦損失が大きい, 特に $\theta=90^{\circ}$ の場合は顕著に大きな 值をとる. しかし $\theta=60^{\circ}$ の場合には，Sh$h_{m}$ が高い值を 示しており, かつ $f$ は比較的に小さいため, 伝熱（物質 移動）促進の効果が充分期待できる.

\section{$2 \cdot 3$ 伝熱性能評価}

流路内に乱れ促進体の挿入による圧力損失を考慮して 伝熱（物質移動）促進効果を比較するため，等ポンプ動 力条件下での性能評価を試みた。

平滑流路と促進体を挿入した場合においてポンプ動力 を同一とすれば，次式の関係が成立する.

$$
f R e^{3}=f_{s} R e_{s}^{3}
$$

上式の左辺に促進体挿入時の摩擦損失係数およびレイ, ルズ数の測定值を代入し， $\left.f_{s} に は \mathrm{Eq} . （ 7\right)$ を用いて対 応する $R e_{s}$ を求める. この $R e_{s}$ を Eq. (6) に代入して, 平滑流路の平均シャーウッド数 $S h_{m s}$ を算出し, ポンプ 動力一定条件下における物質移動促進比（伝熱性能比）

$$
\eta=S h_{m} / S h_{m s}
$$

を求めた. Fig.11 には $\eta-\sqrt[3]{f} \cdot R e$ の関係で示す.

温度 (濃度) 助走区間においてはもともと熱伝達率が 高く, 促進体挿入の効果は完全発達域程期待できないも のの, 低乱流領域では比較的高い促進効果が認められる.

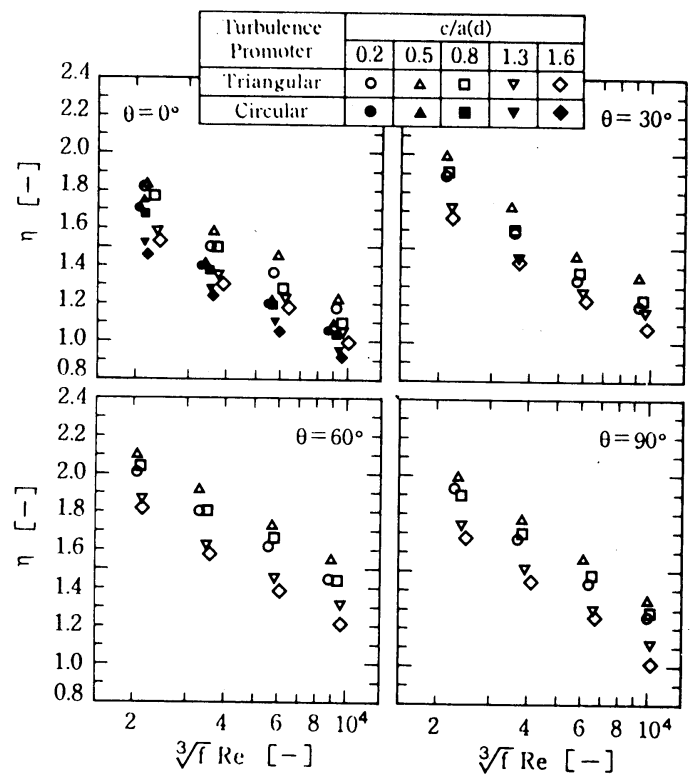

Fig. 11 Performance evaluation based on constant pumping power

いずれも間隙比が 0.5 付近で高い伝熱促進効果を示し, 同じ条件では円柱に比して三角柱の方が性能が優れてい る. 特に迎角 $\theta=60^{\circ}$ の三角柱は卓越した性能を示して いる. $\theta=0^{\circ}$ の場合には相対的に伝熱面近傍で形成さ れる乱れおよび物体からの放出うずが弱く, $\theta=90^{\circ}$ の 場合は, 熱伝達率は高いが圧力損失も大きくなるためい ずれの場合も $\eta$ は低目となる．伝熱性能の向上の観点 からは，間隙流および放出渦による伝熱面近傍での乱流 混合がより活発で，かつ圧力損失が少ないことが望まし く，本実験においては $\theta=60^{\circ}, \quad c / a=0.5$ の正三角柱 が乱れ促進体として最良であるとの結果を得た。

\section{結言}

流れが十分発達した矩形流路内の温度助走区間に伝熱 面から離して正三角柱乱促進体を挿入した場合の熱伝 達特性を把握すべく, 流れの可視化, ナフタリン昇華法 による物質移動係数の測定および圧力損失の測定を行っ た。これらの測定デー夕を基に伝熱性能の評価を行った 結果, 以下の結論を得た。

1）促進体後方における流れの巻き込みによるうずは, 促進体之壁面との間隙の増加に伴い物体後面に近接し, 間隙流は壁噴流型からカルマンうず型に変化する。この 遷移間隙比付近で壁面近傍の乱れおよび乱流混合が最す 活発に行われる.

2） $S h / S h_{s}$ の分布は，三角柱および円柱とも，促進 体の直下およびその下面からはく離したせん断流の再付 
着点近傍でそれぞれ極大值をとるが， $\theta=0^{\circ}$ の三角柱 の場合には $c / a=0.2$ で角柱後方近くにもう一つの極大 值が現れる. 再付着点近傍の極大值は, 間隙比の増加に 伴う巻き込みうずと共に促進体後面に接近した後, 再び 下流に移動する.

3） $S h / S h_{s}$ の第一および第二極大值は共にレイノル ズ数の増加に伴って減少し, その傾向は前者においてよ り顕著である. 迎角の増加は, 流れを壁面方向に導き, 第一極大值の上昇に大きく寄与する.

4）平均シャーゥッド数は間隙比の増加と共に増加し, 間隙流が壁噴流型からカルマンうず型に変る遷移間隙比 で最も大きくなり, その後再び減少する. また, 乱れ促 進体の直下およびその下流で乱流混合が活発に行われる 迎角 $\theta=60^{\circ}$ および $90^{\circ}$ の三角柱が高い平均シャーウッ ド数を示す.

5）流路摩擦損失係数は間隙比の増加之共に增加する が, レイノルズ数の影響は小さい. 三角柱の場合, 同条 件下の円柱に比して圧力損失は高目となる.（しかし $\theta$ $=60^{\circ}$ の場合には圧力損失が比較的低く抑えられる.）

6）ポンプ動力一定条件下での性能評価の結果は, 温 度 (濃度) 助走区間においても低乱流領域ではかなり高 い伝熱促進効果が得られることを示している.さらに, 迎角 $\theta=60^{\circ}$ の正三角柱挿入時には, 間隙比 $c / a=0.5$ で最大性能比 $\eta=2.1$ が得られることから, 乱れ促進体 としての応用が期待できる.

[謝 辞] 本研究の一部は著者の一名（鄭）が嶺南大学校 の学術研究助成費の援助により行い, 海外研究教授派遣計画お よび日本学術振興会の論博プログラムによる訪日研究でまとめ たものである. また実験の遂行においては, 当時同校大学院生 申敏鎬，申暻縈両君の協力を得たことを付記し，ここに合わせ て謝意を表する。

\section{Nomenclature}

$a \quad=$ size of triangular prism

$B \quad=$ height of turbulence promoter

$C=$ concentration of naphthalene vapor

$C_{p}=$ pressure loss coefficient

$\left[\mathrm{kg} / \mathrm{m}^{3}\right]$

$c=$ clearance between a turbulence promoter and wall surface

$D_{h}=$ hydraulic diameter of rectangular duct [m]

$D_{h}{ }^{*}=$ modified hydraulic diameter

$[\mathrm{m}]$

$d=$ diameter of circular cylinder

$f \quad=$ friction factor

$H=$ height of rectangular duct

$K=$ local mass transfer coefficient
$L=$ distance between reference pressure tap and the last pressure tap on test section [m]

$m=$ exponent of Reynolds number $\quad[-]$

$p \quad=$ static pressure

$p_{0}=$ reference static pressure

$Q=$ volumetric air flow rate $\left[\mathrm{m}^{3} / \mathrm{s}\right]$

$R e=$ Reynolds number $\left(=D_{h} U_{m} / \nu\right)$

$R e^{*}=$ modified Reynolds number $\left(=D_{h}{ }^{*} U_{m} / \nu\right)$

$S c=$ Schmidt number

$S h=$ local Sherwood number $\left(=K D_{h} S c / \nu\right)$

$T=$ temperature

$U$ = uncertainty

$U_{m}=$ bulk mean velocity

$W=$ width of naphthalene plate $[\mathrm{m} / \mathrm{s}]$

$X \quad$ streamwise distance from upstream edge of test plate

$X_{p}=$ streamwise distance from location of turbulence promoter

$x, y=$ coordinates of test section

$\Delta p=$ pressure difference across the distance $L$

$\Delta t=$ duration time of data run

$\Delta \tau=$ local change in height of naphthalene surface sublimated during data run $[\mathrm{m}]$

$\eta \quad=$ performance evaluation $\quad[-]$

$\theta \quad=$ angle of attack for triangular prism

$\nu=$ kinematic viscosity of air $\quad\left[\mathrm{m}^{2} / \mathrm{s}\right]$

$\rho=$ air density $\quad\left[\mathrm{kg} / \mathrm{m}^{3}\right]$

$\rho_{s}=$ density of solid naphthalene $(=1145)$

$\left[\mathrm{kg} / \mathrm{m}^{3}\right]$

$<$ Subscripts $>$

$b \quad=$ bulk

$m$ = mean value

$\max =$ maximum value

$s \quad=$ smooth duct

$w \quad$ wall

\section{Literature cited}

1) Cho, K., T. F. Irvine, Jr. and J. Karni: Int. J. Heat Mass Transfer, 35, $957-966$ (1992)

2) Chung, I. K., A. Nakayama, H. Koyama and A. Araki: Fluid \& Heat Eng. Res, 28, 25 - 32 (1993)

3) Chung, I. K., N. Araki and A. Nakayama: JSME, B, 60, 574, $2149-2157$ (1994)

4) Fujita, H., H. Takahama and R. Yamashita: JSME B, 42, 
$2828-2836$ (1976)

5) Gnielinski, V.: Int. Chem. Engng., 16, 359 - 368 (1976)

6) Jones, O.C. Jr.: Trans. ASME J. Fluids Eng., 98, $173-$ 181 (1976)

7) Kline, S. J. and F. A. McClintock: Mech. Eng., 75, 3-8 (1953)

8) Miyashita, H., Y. Shiomi and K. Wakabayashi:Kagaku Kogaku Ronbunshu, 7, 349-354 (1981)

9) Miyashita, H., Y.Kondo, T. Hata and T. Nishimura: ibid., 17, $380-386$ (1991)

10) Miyashita, H., M. Yoshida, Y. Kondo and T. Nishimura: ibid., 18, $189-195$ (1992)

11) Oyakawa, K. and I. Mabuchi: JSME B, 47, 308-316 (1981)
12) Sogin, H. H.: Trans. ASME, 80, $61-69$ (1958)

13) Sparrow, E. M. and N. Cur: Trans. ASME, Ser. C, 104, $82-89$ (1982)

14) Suzuki, H., K. Suzuki, Y. Inoue and Y. Hagiwara: JSME $B, \mathbf{5 7}, 1403-1409$ (1991)

15) Suzuki, H., K. Fukutani, T. Takishita and K. Suzuki: ibid., 59, $1692-1697$ (1993)

16) Tanasawa, I., S. Nishio, K. Takano and M. Tawatari: JSME B., 49, 676-684 (1983)

17) Taniguchi, S., K. Miyakoshi and S. Dohda: ibid., 51, 1619 - 1623 (1985)

18) Watson, J. S. and D. G. Thomas: AIChE J., 13, 676-677 (1967)

\title{
Heat Transfer Enhancement of a Thermally Developing Region in a Rectangular Channel with a Turbulence Promoter
}

\author{
In Kee Chung
}

Dept. of Mechanical Eng., Yeungnam Univ., Gyongsan 712-749, Korea

Akira Nakayama and Nobuyuki Araki

Dept. of Energy and Mechanical Eng., Shizuoka Univ., Hamamatsu 432

\begin{abstract}
Key Words : Heat Transfer, Heat Transfer Enhancement, Turbulence Promoter, Thermally Developing Region, Naphthalene Sublimation Technique, Flow Visualization, Performance Evaluation
\end{abstract}

An experimental study was carried out to investigate heat/mass transfer enhancement with a triangular prism as a turbulence promoter, for a hydrodynamically developed and thermally developing region in a rectangular channel. Measurements of local mass transfer coefficients were made using a naphthalene sublimation technique, varying the clearance between the promoter and mass transfer surface and the angle of attack of the triangular prism, for Reynolds numbers ranging from 4960 to 22,050 . Flow visualization was also carried out, utilizing an oil film method. Performance evaluation based on equal pumping power reveals that substantial augmentation of heat transfer is possible for turbulent flows at low Reynolds numbers in a thermally developing region by use of a triangular prism placed for optimal clearance ratio and angle of attack. 